\title{
Long term therapy for gastroesophageal reflux disease - Who and with what?
}

\author{
WG PATERSON, MD, FRCPC
}

\begin{abstract}
WG PATERSON. Long term therapy for gastroesophageal reflux disease - Who and with what? Can J Gastroenterol 1993;7(5):422-426. In general, gastroesophageal reflux disease (GERD) is a chronic relapsing condition. Some patients can effectively reverse or at least control the disease long term by instituting specific lifestyle modifications and/or by using over-the-counter antacid or alginate preparations. In patients with severe forms of the disease more intensive long term therapy is usually required; however, it is sometimes difficult to predict which patients will require long term maintenance therapy. Three classes of drug $-\mathrm{H}_{2}$ receptors antagonists, prokinetic agents and proton pump inhibitors - have been evaluated in the long term treatment of GERD. Of these, the proton pump inhibitor omeprazole is undoubtedly the most efficacious, but most gastroenterologists would confine its use to patients with more severe forms of the disease, whose symptoms cannot be maintained in remission on $\mathrm{H}_{2}$ receptor antagonists or prokinetics. In selected patients antireflux surgery should be considered as a means of controlling the disease long term, providing one recognizes that surgical expertise in this area is not universal.
\end{abstract}

Key Words: Gastroesophageal reflux disease (GERD), $\mathrm{H}_{2}$ receptor antagonists, Prokinetic agents, Proton pump inhibitors

\section{Traitement à long terme du reflux gastro-œesophagien: à qui et comment?}

RÉSUMÉ: En général, le reflux gastro-øesophagien est une maladie récidivante chronique. Certains patients peuvent éliminer ou au moins mâtriser la maladie à long terme par l'adoption de modifications précises à leur mode de vie et/ou par le recours à des préparations d'anti-acides ou d'alginates vendues sans ordonnance. Chez les patients qui souffrent de la maladie à un degré élevé, un traitement à long terme plus intensif est généralement requis. Cependant, il est parfois difficile de

Gastrointestinal Diseases Research Unit and Departments of Medicine and Physiology,

Queen's University, Kingston, Ontario

Correspondence: Dr WG Paterson, Division of Gastroenterology, Hotel Dien Hospital, 166 Brock Street, Kingston, Ontario K7L.5G2. Telephone (613) 549-5615
T HE PAST DECADE HAS SEEN MAJOR advances in our understanding of the pathophysiology and management of gastroesophageal reflux disease (GERD). With the addition of the proton pump inhibitor omeprazole to our therapeutic armamentarium, symptom control and healing of esophagitis is possible in virtually every patient with acid reflux esophagitis $(1,2)$. In most patients, however, GERD is a chronic relapsing condition (3). In fact, in patients with erosive esophagitis healed with antisecretory treatment, the six month relapse rate is as high as $80 \%$ following cessation of therapy (4). Thus, in most patients some form of long term therapy is required to keep the disease under control. To date, however, no clear consensus has emerged regarding which patients require long term drug therapy for GERD and which agent(s) should be used.

\section{LONG TERM MAINTENANCE THERAPY FOR GERD - WHO SHOULD BE TREATED?}

Given the high relapse rate in patients with reflux esophagitis, it may be more germane to ask the question which patients do not require long term 
prédire quels patients auront besoin d'un traitement d'entretien prolongé. Trois classes de médicaments, les inhibiteurs $\mathrm{H}_{2}$, les agents procinétiques et les inhibiteurs de la pompe à protons ont été passés en revue pour ce qui est du traitement à long terme du reflux gastro-cesophagien. De ces trois classes, l'inhibiteur de la pompe à protons oméprazole est sans contredit le plus efficace mais la plupart des gastro-entérologues en restreignent l'usage aux patients atteints des formes les plus graves de la maladie, dont les symptômes ne peuvent être maintenus en rémission par les inhibiteurs $\mathrm{H}_{2}$ ou les procinétiques. Chez certains patients, la chirurgie anti-reflux doit être envisagée pour maîtriser la maladie à long terme, à condition de se rappeler que l'expertise chirurgicale dans ce domaine n'est pas universelle. maintenance therapy for GERD? Certainly, patients with mild symptoms that respond to lifestyle modifications and over-the-counter antacid preparations may not require long term pharmacological therapy. This is particularly the case if a specific lifestyle precipitant can be eliminated (eg, excessive coffee or alcohol intake, obesity etc). Similarly, if the GERD was precipitated by a drug (eg, tricyclic antidepressants, estrogen-progestin combination) that can be discontinued, the patient may not require ongoing treatment.

On the other hand, there are certain patients in whom the need for long term pharmacological therapy is predictable. This would include patients with complicated GERD - ulcerative esophagitis, peptic stricture, Barrett's esophagus and reflux esophagitis with scleroderma esophagus - or patients with reflux esophagitis who don't respond to standard dose $\mathrm{H}_{2}$ receptor antagonists or prokinetics. In between these extremes lies the majority of patients with GERD in whom the need for long term therapy is usually established by trial and error.

\section{THERAPEUTIC OPTIONS}

Table I summarizes the various therapeutic options in the long term treatment of GERD. Although controlled clinical trials have validated most of the pharmacological interventions in the acute treatment of GERD, few published studies have looked at the long term efficacy of these drugs. Clinical experience would suggest that antacid and alginate preparations are effective in relieving symptoms on an as required basis long term in patients with mild disease. In patients with more significant disease the current options are $\mathrm{H}_{2}$ receptor antagonists, prokinetic agents, the proton pump inhibitor omeprazole, or antireflux surgery.

$\mathrm{H}_{2}$ receptor antagonists: $\mathrm{H}_{2}$ receptor antagonists are the most commonly used drugs in both the short and long term treatment of (GERD, yet there is little support in the literature for their efficacy as maintenance agents (Table 2). Several of the reports to date have only been published in abstract form

TABLE 1

Therapeutic options in the long term treatment of reflux esophagitis

Pharmacological
$\mathrm{H}_{2}$ receptor antagonists
Cimetidine, famotidine, nizatidine.
ranitidine
Prokinetics
Cisapride, domperidone,
metoclopramide
Proton pump inhibitor
Omeprazole, lansoprazole
Miscellaneous
Sucralfate, alginate, antacids
Antireflux surgery
Besley, Hill, Nissen

$(5,6,9,10)$ and only one found that maintenance $\mathrm{H}_{2}$ receptor antagonist therapy was efficacious (6). However, most of these studies were designed along the lines of the maintenance trials for duodenal ulcer disease in which a once daily or reduced dose regimen

\section{TABLE 2}

$\mathrm{H}_{2}$ receptor antagonists as maintenance therapy for GERD - Results of controlled trials

\begin{tabular}{|c|c|c|c|}
\hline $\begin{array}{l}\text { Author } \\
\text { (reference) }\end{array}$ & $\mathrm{H}_{2}$ blocker regimen & Duration & Results \\
\hline $\begin{array}{l}\text { Bright-Asare, } \\
1982\left(5^{*}\right)\end{array}$ & $\begin{array}{l}\text { Cimetidine } 400 \mathrm{mg} \text { at } \\
\text { bedtime or } 300 \mathrm{mg} \text { bid }\end{array}$ & 6 months & $\begin{array}{l}\text { Neither regimen better } \\
\text { than placebo }\end{array}$ \\
\hline $\begin{array}{l}\text { McCallum. } \\
1985\left(6^{\circ}\right)\end{array}$ & $\begin{array}{l}\text { Ranitidine } 150 \mathrm{mg} \text { at } \\
\text { bedtime or } 150 \mathrm{mg} \text { bid }\end{array}$ & 12 months & $\begin{array}{l}\text { bid better than at } \\
\text { bedtime regimen }\end{array}$ \\
\hline Kaul, 1986 (7) & $\begin{array}{l}\text { Cimetidine } 400 \mathrm{mg} \text { at } \\
\text { bedtime }\end{array}$ & 6 months & No better than placebo \\
\hline Koelz, $1986(8)$ & $\begin{array}{l}\text { Ranitidine } 150 \mathrm{mg} \text { at } \\
\text { bedtime }\end{array}$ & 6 months & No better than placebo \\
\hline $\begin{array}{l}\text { Armstrong. } \\
1989\left(9^{*}\right)\end{array}$ & $\begin{array}{l}\text { Ranitidine } 150 \mathrm{mg} \text { bid or } \\
300 \mathrm{mg} \text { at bedtime }\end{array}$ & 6 months & No better than placebo \\
\hline $\begin{array}{l}\text { Berlin, } 1989 \\
\left(10^{*}\right)\end{array}$ & $\begin{array}{l}\text { Famotidine } 20 \mathrm{mg} \text { or } \\
40 \mathrm{mg} \text { at bedtime }\end{array}$ & 6 months & No better than placebo \\
\hline
\end{tabular}

-Abstract

TABLE 3

Cisapride as maintenance therapy for GERD: Results of controlled trials

\begin{tabular}{|c|c|c|c|}
\hline $\begin{array}{l}\text { Author } \\
\text { (reference) }\end{array}$ & Cisapride regimen & Duration & Results \\
\hline $\begin{array}{l}\text { Toussant, } \\
1991 \text { (12) }\end{array}$ & $\begin{array}{l}10 \text { mg po bid versus } \\
\text { placebo }\end{array}$ & 6 months & $\begin{array}{l}\text { Cisapride better than placebo } \\
(P=0.06)\end{array}$ \\
\hline $\begin{array}{l}\text { Tytgat, } \\
1992 \text { (13) }\end{array}$ & $\begin{array}{l}20 \text { mg po bid versus } \\
\text { placebo }\end{array}$ & 6 months & $\begin{array}{l}\text { Cisapride better than placebo re: } \\
\text { symptom relapse: endoscopic } \\
\text { relapse only significantly better in } \\
\text { patients with grade I esophagitis }\end{array}$ \\
\hline $\begin{array}{l}\text { Blum. } \\
\qquad 1993(14)\end{array}$ & $\begin{array}{l}10 \mathrm{mg} \text { po bid or } 20 \mathrm{mg} \\
\text { po at bedtime versus } \\
\text { placebo }\end{array}$ & 12 months & $\begin{array}{l}\text { Both cisapride regimens better } \\
\text { than placebo }\end{array}$ \\
\hline
\end{tabular}


TABLE 4

Omeprazole as maintenance therapy for GERD: Results of controlled trials

\begin{tabular}{|c|c|c|c|}
\hline $\begin{array}{l}\text { Author } \\
\text { (reference) }\end{array}$ & Regimen & Duration & Results \\
\hline $\begin{array}{l}\text { Dent, } 1990 \\
\text { (17) }\end{array}$ & $\begin{array}{l}\text { Omeprazole } 20 \text { mg od } \\
\text { versus } 20 \text { mg every Friday, } \\
\text { Saturday and Sunday versus } \\
\text { ranitidine } 150 \mathrm{mg} \text { po bid }\end{array}$ & 12 months & $\begin{array}{l}\text { Highly significant } \\
\text { advantage in daily } \\
\text { omeprazole group }\end{array}$ \\
\hline $\begin{array}{l}\text { Lundell, } \\
1991 \text { (18) }\end{array}$ & $\begin{array}{l}\text { Omeprazole } 20 \mathrm{mg} \text { po od } \\
\text { versus ranitidine } 150 \mathrm{mg} \text { po } \\
\text { bid }\end{array}$ & 12 months & $\begin{array}{l}\text { Highly significant } \\
\text { advantage in daily } \\
\text { omeprazole group }\end{array}$ \\
\hline $\begin{array}{l}\text { Zeitoun, } \\
1989 \text { (19) }\end{array}$ & $\begin{array}{l}\text { Omeprazole } 10 \text { mg po od } \\
\text { versus } 20 \text { mg every Friday, } \\
\text { Saturday and Sunday }\end{array}$ & 6 months & $\begin{array}{l}\text { Daily low dose omeprazole } \\
\text { better than weekend } \\
\text { omeprazole }\end{array}$ \\
\hline
\end{tabular}

had been found to be effective. It is now apparent that more potent acid suppression is required in the treatment of reflux esophagitis, and that in most cases a once daily dosing schedule is inappropriate (11). Thus, one should not put too much weight on these negative studies. Clinical experience would suggest that $\mathrm{H}_{2}$ receptor antagonists, when used in appropriate dosage, are efficacious in the long term treatment of patients with mild to moderate GERD.

Prokinetic agents: Of the prokinetic agents, only cisapride has been subjected to trials as maintenance therapy for GERD (Table 3). Toussant et al (12) randomized 80 patients who had initially healed their reflux esophagitis on cisapride $10 \mathrm{mg}$ gid to maintenance therapy with either cisapride $10 \mathrm{mg}$ bid or placebo. The six month relapse rate was $20 \%$ in the cisapride group versus $39 \%$ in the placebo group $(\mathrm{P}=0.06)$. In a similar study (13), 298 patients with reflux esophagitis healed initially with antisecretory agents were randomized to cisapride $20 \mathrm{mg}$ bid or placebo and followed for up to six months or until symptomatic relapse occurred. Overall, cisapride was more effective than placebo in terms of symptomatic relapse, but efficacy in terms of preventing relapse of endoscopic esophagitis was only apparent in the subgroup of patients who initially had the mildest form of esophagitis (grade 1). Another study by Blum et al (14) randomized 443 patients healed initially with antisecretory therapy to maintenance therapy with either cisapride $10 \mathrm{mg}$ bid, cisapride $20 \mathrm{mg}$ at bedtime, or placebo. The one-year relapse rate favoured the cisapride treated groups with approximately $28 \%$ relapsing in each of the cisapride groups compared with $49 \%$ in the placebo group.

It would thus appear that prokinetics are efficacious as maintenance therapy in patients with reflux disease of mild to moderate severity. Prokinetics are also often used in combination with antisecretory agents in the treatment of reflux esophagitis, an approach that has been supported in acute healing studies $(15,16)$. No controlled trials using combination therapy as maintenance treatment in GERD have been reported. Proton pump inhibitors - omeprazole: Several recent controlled clinical trials have compared omeprazole with ranitidine as maintenance therapy following healing of reflux esophagitis (Table 4). Dent and colleagues (17) randomized 159 patients, who had healed their esophagitis on $20 \mathrm{mg}$ of omeprazole per day, to either ranitidine $150 \mathrm{mg}$ bid, omeprazole $20 \mathrm{mg}$ daily each Friday, Saturday and Sunday (weekend therapy) or omeprazole $20 \mathrm{mg}$ daily. Results strongly favoured daily omeprazole therapy with $89 \%$ of this group remaining in symptomatic and endoscopic remission at 12 months versus $32 \%$ in the weekend omeprazole group and $25 \%$ in the ranitidine group. In a Scandinavian study (18) 98 patients with $\mathrm{H}_{2}$ receptor antagonist resistant reflux esophagitis (ie, unhealed after three months of treatment with $1200 \mathrm{mg}$ or more of cimetidine per day or $300 \mathrm{mg}$ or more of ranitidine per day) were randomized to either $40 \mathrm{mg}$ once daily of omeprazole versus ranitidine $300 \mathrm{mg}$ bid. Subsequent healing rates were $90 \%$ in the omepra- zole group and $47 \%$ in the ranitidine group. Patients healed on $40 \mathrm{mg}$ of omeprazole were then given omeprazole 20 $\mathrm{mg} /$ day, whereas patients healed with $600 \mathrm{mg}$ of ranitidine were given 300 $\mathrm{mg} /$ day as maintenance therapy. Remission rates at 12 months strongly favoured the omeprazole group $(67 \%$ versus $10 \%$ ).

Finally, a study from Europe (19) randomized 87 patients to six months of therapy with either omeprazole 20 mg on Friday, Saturday and Sunday, or omeprazole $10 \mathrm{mg}$ once daily after they had healed their reflux esophagitis acutely with $20 \mathrm{mg} /$ day of omeprazole. Relapse rate was $54 \%$ in the weekend omeprazole group versus $21 \%$ in the 10 $\mathrm{mg} /$ day omeprazole group.

These studies support the efficacy of omeprazole as maintenance therapy for GERD over a six - to 12 -month period. However, in many patients reflux is a life-long problem and the efficacy and safety of treatment beyond 12 months is uncertain. Open studies from Europe suggest that continuous omeprazole therapy will keep patients in remission over several years without any untoward effects $(2,20)$. These studies suggest that of the patients with reflux esophagitis poorly responsive to $\mathrm{H}_{2}$ receptor antagonists who are subsequently put on long term omeprazole therapy, approximately two-thirds are adequately maintained on $20 \mathrm{mg}$ of omeprazole per day, whereas the remainder have to have their dose increased to $40 \mathrm{mg} /$ day. Rarely, patients will require greater than $40 \mathrm{mg} /$ day of omeprazole. In these patients, $24 \mathrm{~h} \mathrm{pH}$ monitoring usually reveals that gastric $\mathrm{pH}$ declines in the evening, indicating that the effect of the morning dose of omeprazole has dissipated. In this setting a bid dose regimen is required.

Another setting where long term omeprazole therapy should be considered is in patients with peptic stricture. A recent study (published in abstract form) suggests that patients treated with omeprazole long term compared with ranitidine require less frequent esophageal dilations for recurrent peptic stricture (21).

Antireflux surgery: A number of surgical centres have performed careful fol- 
low-up studies in patients undergoing antireflux surgery (22-29). Most of these studies are subject to observer bias; nevertheless, the efficacy of surgical treatment for (GERD is well accepted. A recent large, randomized prospective Veterans Administration study in the United States comparing antireflux surgery with medical treatment demonstrated improved results in patients randomized to surgery (23). However, this well designed study was ohsolete by the time it was published in that it was performed before omeprazole was licensed in the United States. It is very unlikely that similar results would have been obtained if surgery was compared with omeprazole treatment, particularly if the protocol allowed for individualized upward adjustment of the omeprazole dosage.

In expert hands, good to excellent short term results are obtained in approximately 85 to $90 \%$ of patients undergoing either one of the three major antireflux operations (Nissen fundoplication, Hill posterior gastropexy or Belsey mark IV procedure). Some surgeons have reported that these results are maintained for several years $(22,25,26)$. Unfortunately, such excellent results are not universal $(27,28)$. Furthermore, a significant number of patients will experience surgical morbidity such as splenectomy, dysphagia and gas hloat

\section{REFERENCES}

1. Marciano-D'Amore DA, Paterson WG, DaCosta LR, et al. Omeprazole in $\mathrm{H}_{2}$ receptor antagonist-resistant reflux esophagitis. J Clin Gastroenterol 1990;12:616-20.

2. Klinkenberg-Knol EC, Meuwissen SGM. Medical therapy of patients with reflux esophagitis poorly responsive to $\mathrm{H}_{2}$-receptor antagonist therapy. Digestion 1992;51 (Suppl 1):44-8.

3. Spechler SJ. Epidemiology and natural history of gastroesophageal reflux disease. Digestion 1992;51 (Suppl 1):24-9.

4. Hetzel DJ, Dent J, Reed WD, et al. Healing and relapse of severe peptic esophagitis after treatment with omeprazole. Gastroenterology 1988;95:903-12

5. Bright-Asare P, Behar J, Brand DL, et al. Effects of long-term maintenance cimetidine on gastroesophageal reflux syndrome. There is also a small but definite risk of mortality $(0.4 \%$ in a recent large series) (22). Morbidity and mortality increases with 'redo' operations and the chance of successful outcome is significantly diminished. There is also evidence that antireflux surgery is least effective in patients with the more severe forms of esophagitis and peptic stricture $(27,29)$.

\section{LONG TERM TREATMENT OF GERD IN THE 1990s - A SUGGESTED APPROACH}

In view of the paucity of good scientific data on which to base decisions, long term maintenance treatment for (GFRD) is by necessity founded on good clinical judgement and common sense. In patients with mild to moderate disease it is reasonable to discontinue drug therapy once symptoms and/or esophagitis have been controlled with acute treatment. Many patients will remain well by following lifestyle modifications alone. If there is a symptom relapse one should try the least expensive and least potent drug regimen that controls symptoms (eg, hid $\mathrm{H}_{2}$ receptor antagonists or cisapride). In patients with persistent symptoms despite $\mathrm{H}_{2}$ receptor antagonist treatment using 'above average' dose (eg, cimetidine $1800 \mathrm{mg} /$ day, ranitidine $450 \mathrm{mg} /$ day or equivalent), omeprazole should be

disease. Gastroenterology 1982;82:1025. (Abst)

6. McCallum RW, Sontag SI, Vlahcevick ZR, et al. Ranitidine versus placeho in long-term treatment of gastroesophageal reflux. Am J Gastroenterol 1985;80:864. (Abst)

7. Kaul B, Petersen H, Erichsen H, et al. Gastroesophageal reflux disease: Acute and maintenance treatments with cimetidine. Scand ] Gastroenterol 1986:21:139.45

8. Koelz HR, Birchler R, Bretholz A. et al. Healing and relapse of reflux esophagitis during treatment with ranitidine. Gastroenterology 1986;91:1198-205.

9. Armstrong D, Blum AL, and the REZITIC study group. Full dose $\mathrm{H}_{2}$ receptor antagonist prophylaxis does not prevent relapse of reflux esophagitis. Gut 1989;30:A1494.

10. Berlin R, Ehel D, Cook T. Famotidine (F) $20 \mathrm{hs}$ and $40 \mathrm{hs}$ versus placebo ( $\Gamma)$. in the maintenance therapy (MT) of used. Long term omeprazole should probably also be used in patients with reflux esophagitis complicated hy peptic stricture.

The decision to resort to antireflux surgery depends on a number of factors. including patient preference, the availability of a surgeon with special expertise in antireflux surgery and cost. The risks and benefits of surgery versus long term drug therapy need to be carefully explained to each patient. Clearly, surgery is an important option in the rare patient who is unresponsive or intolerant to medical therapy. It also should he seriously considered in young (less than 40 years old) healthy patients who require omeprazole to control their disease and are thus facing the option of life long treatment with an expensive and potent drug. When given the choice, however, most of these patients choose long term omeprazole therapy, particularly if the drug is paid for by an insurance plan. One of the major indications for antireflux surgery is the patients' inability to afford drug therapy in the setting where the costs of surgical therapy are fully insured. The issue of the cost-benefit ratio of medical versus surgical therapy is a difficult one that is unlikely to be clarified in the near future. Any such comparison would have to factor in the cost of mortality, which clearly cannot be objectively allocated.

reflux esophagitis (RE). Results of at double-blind, multicenter trial. Gastroenterology 1989;96:A39

11. Cloud ML, Offen WW, Rohinsin M. Nizattidine versus placebo in gastrocsophageal reflux disease: A 12 week, multicenter, randomized, double hind study. Am I Gastroenterol 1991;86:1735-42.

12. Toussaint J, Grossuin A, Deruyttere M, et al. Healing and prevention of relapse of reflux oesophagitis by cisapride. Gut 1991;32:1280-5.

13. Tytgar GNJ, Anker-Hansen OJ, Carling L, et al. Effect of cisapride on relapse of reflux oesophagitis, healed with an antisecretory drug. Scand J Gastroenterol 1992;27:175-83.

14. Blum AL, Adami B, Bouzo MH, er al. Effect of cisapride on relapse of esophagitis: A multinational, placebo-controlled trial in patients healed with an anti-secretory drug. Dig Dis So 1993:38:551-60.

15. Lieberman DA, Keeffe EB. Treatment 
of severe reflux esophagitis with cimetidine and metoclopramide. Ann Int Med 1986;104:21-6.

16. Galmiche JP, Brandstatter G, Evreux $\mathrm{M}$, et al. Combined therapy with cisapride and cimetidine in severe reflux oesophagitis: A double blind controlled trial. Gut 1988;29:675-81.

17. Dent J. Australian clinical trials of omeprazole in the management of reflux oesophagitis. Digestion 1990;47(Suppl 1):69-71.

18. Lundell L, Beckman L. Ekstrom P, et al. Prevention of relapse of reflux esophagit is after endoscopic healing: The efficacy and safety of omeprazole compared with ranitidine. Scan J Gastroenterol 1991:26:248-56.

19. Zeitoun P, Barbier P, Cayphas JP, et al. Comparison of two dosage regimes of omeprazole $-10 \mathrm{mg}$ once daily and $20 \mathrm{mg}$ weekends as prophylax is against recurrence of reflux esophagitis. Hepatogastroenterology 1989;36:279-80.

20. Koop H, Amold R. Longterm maintenance treatment of reflux esophagit is with omeprazole:

Prospective study in patients with $\mathrm{H}_{2}$ blocker resistant esophagitis. Dig Dis Sci 1991;36:552-7.

21. Marks R, Richter JE, Koehler R, et al. Does medical therapy improve dysphagia in patients with peptic strictures and esophagit is? Gastroenterology 1992;102:A118.

22. Csendes A, Braghetro I, Kom O, et al. Late subjective and objective evaluations of antireflux surgery in patients with reflux esophagitis: Analysis of 215 patients. Surgery 1989;105:374-82.

23. Spechler SI and the Department of Veteran Affairs Gastroesophageal Reflux Disease Study Group. Comparison of medical and surgical therapy for complicated gastroesophageal reflux discase in veterans. $\mathrm{N}$ Engl J Med 1992; 326:786-92.

24. Martinez de Haro LF, Ortiz A, Parrilla $\mathrm{P}$, et al. Long term results of Nissen fundoplication in reflux esophagitis without strictures: Clinical, endoscopic, and $\mathrm{pH}$-metric evaluation. Dig Dis Sci 1992;37:523-7.

25. Johansson J, Johnsson F. Joelsson B, et al. Outcome 5 years after $360^{\circ}$ fundoplication for gastrooesophageal reflux disease. $\mathrm{Br}$ I Surg 1993;80:46-9.

26. Low DE, Anderson RP, Ilves R, et al. Fifteen-to-twenty-year results after the Hill antireflux operation. J Thorac Cardioyase Surg 1989;98:444-50.

27. Salama FD, Lamont G. Long-term results of the Belsey Mark IV anti-reflux operation in relation to the severity of esophagitis. I Thorac Cardiovase Surg 1990;100:517-9.

28. Brand DL, Eastwood IR, Martin D, et al. Esophageal symptoms, manometry, and histology before and after anti-reflux surgery. Gastroenterology 1979;76:1393-401.

29. Mercer CD, Hill LD. Surgical management of peptic esophageal stricture: Twenty-year experience. ] Thorac Cardiovasc Surg 1986;91:371-8. 


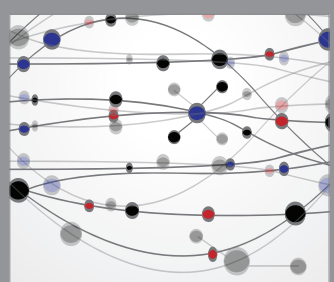

The Scientific World Journal
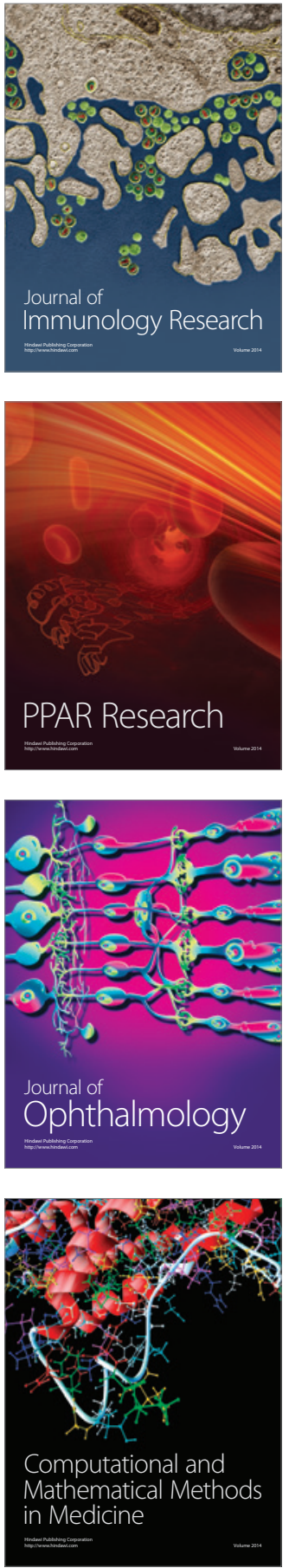

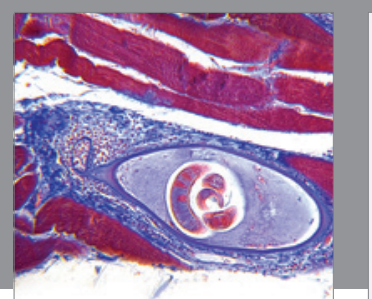

Gastroenterology Research and Practice

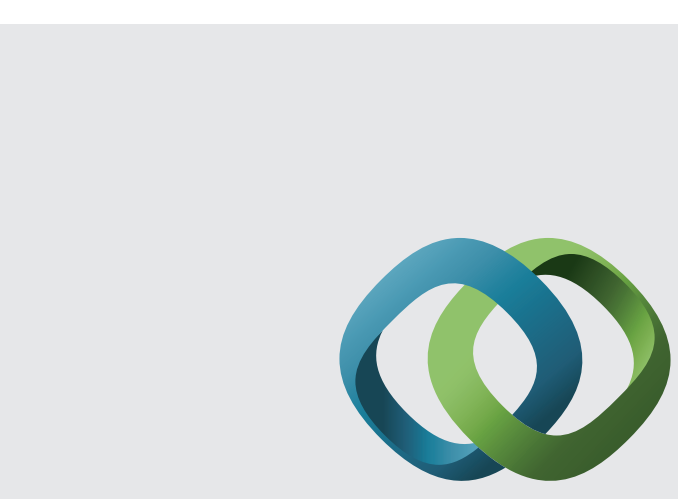

\section{Hindawi}

Submit your manuscripts at

http://www.hindawi.com
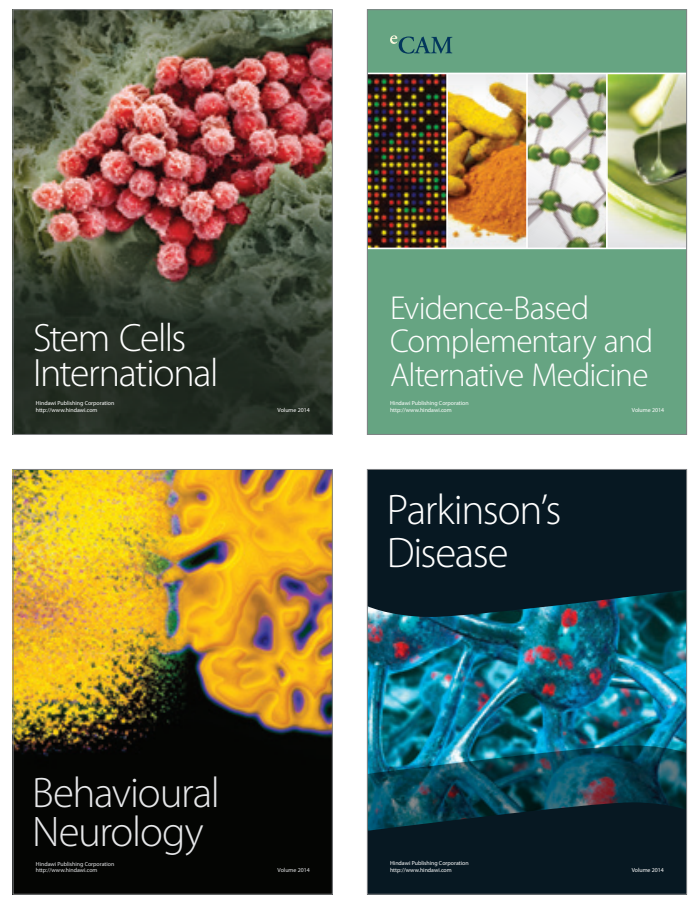
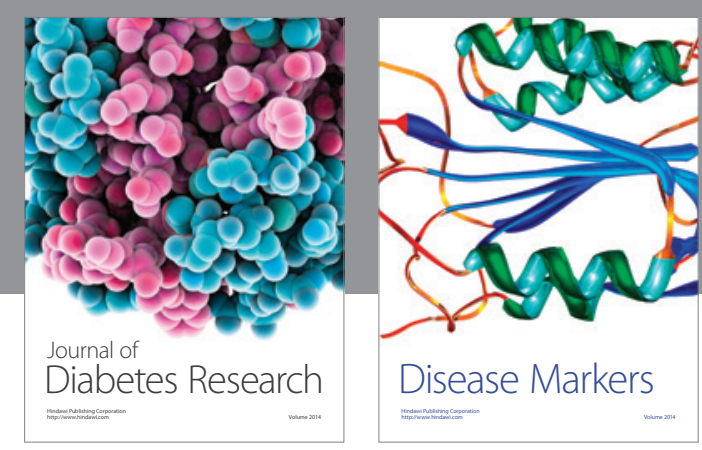

Disease Markers
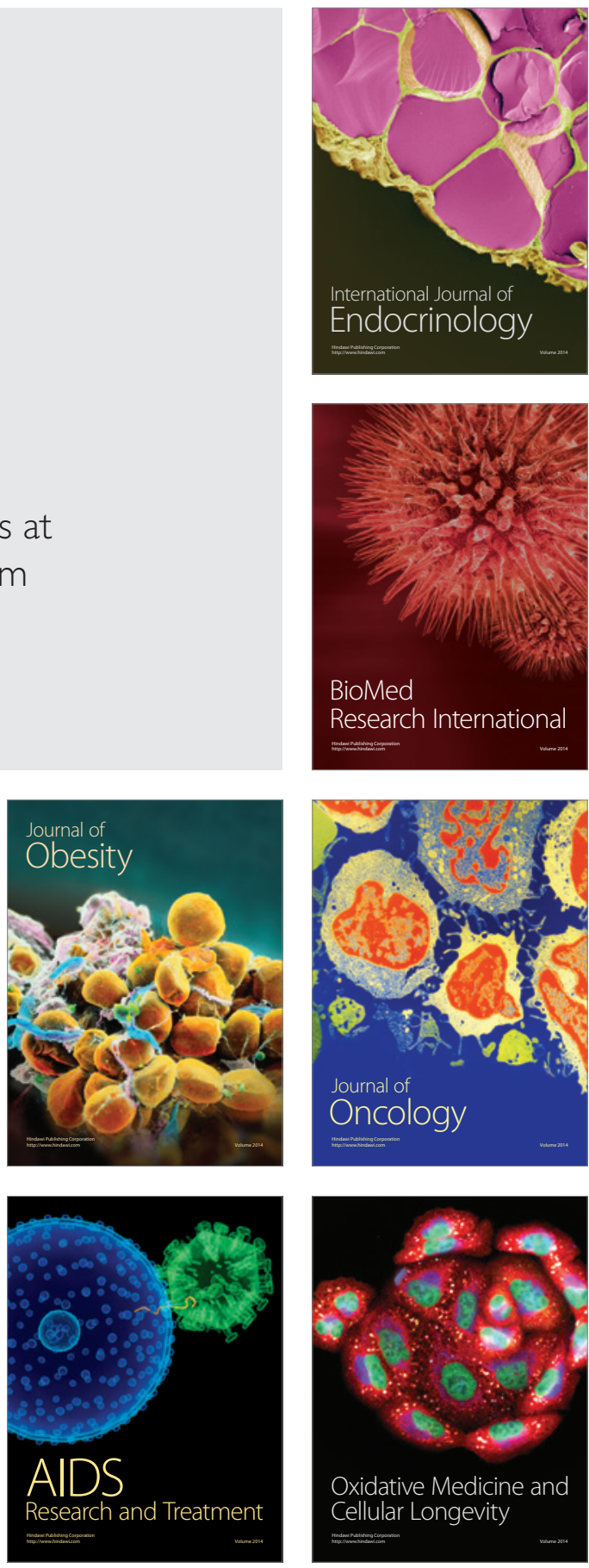